\title{
Land Registration Concepts in Translation
}

\author{
Jan Gościński ${ }^{1}$ (D) Artur D. Kubacki ${ }^{1}$ (D)
}

Accepted: 4 November 2020 / Published online: 19 November 2020

(c) The Author(s) 2020

\begin{abstract}
Land registration systems are used throughout the world in order to store information on the ownership of land, rights attached to it, and burdens affecting it. A smoothly functioning land registration system guarantees the security of land transfer operations. However, there are significant differences in the way national land registration systems are run due to their historical development and divergent legislative approaches to land registration. Consequently, the need arises to compare different systems so as to find both common ground and discrepancies between them. The paper contains such a comparative analysis which has been carried out with translation in mind: to discover the best ways of transferring land registration legal concepts expressed in one linguistic framework and characteristic of a given legal culture into target legal spaces using other linguistic frameworks. The comparison in question has taken place in a third space, a space where selected aspects of selected legal systems mingle revealing more or less clear similarities and more or less distinct differences between them. The juxtaposition of source and target legal cultures in a third space has resulted in finding translation equivalents that do not abuse (traumatize) the original ideas or-if this has been unavoidable-abuse them to the smallest extent possible. The analysis has covered the Polish land registration system and equivalent systems in English- and German-speaking countries (England and Wales, Scotland, Northern Ireland, Ireland, the USA, Austria, Germany, Switzerland) and has been conducted from the point of view of a Polish-English and Polish-German translator.
\end{abstract}

Keywords Comparative law $\cdot$ Land registration · Translation equivalence $\cdot$ Third space $\cdot$ Intercultural communication

Jan Gościński

jango@post.pl

Artur D. Kubacki

kubart@post.pl

1 Pedagogical University of Kraków, Kraków, Poland 


\section{Introduction}

Put succinctly, "the translator of a legal text aims at introducing foreign legal worldviews into a different legal life-world. His task is to make the foreign legal text accessible for recipients with a different (legal) background" [24, p. 283]. As "law and legal language are system-bound, that is, they reflect the history, evolution and culture of a specific legal system" [6, p. 23], legal translation clearly belongs to "the area of intercultural communication, requiring not only language mediation but heightened cultural expertise" [28, p. 133]. Anne Wagner proposes a new theoretical framework, explaining how this process of intercultural communication in the field of law comes to fruition. The novel theory draws on a concept developed by Homi Bhabha. He states [26, p. 211] that "all forms of culture are continually in a process of hybridity", adding that for him "the importance of hybridity is not to be able to trace two original moments from which the third emerges, rather hybridity (...) is the 'third space' which enables other positions to emerge." Anne Wagner perceives this notion as particularly useful for legal translators. They operate within a linguistic framework being-as she points out [36, p. 169]- “originally a binary code that comprises two semantic spaces: the source space and the target space." However, the process of legal translation constitutes a third space, "a space in-between", "undefined, vague, and fluid", "a precondition for the negotiation, transformation and translation (...) between two cultures", "where mechanisms of transfer, of importation from one culture to another have to be fairly analysed" [36, pp. 169-170].

As a third space is "entwined in the source space and the target space" [36, p. 173], it creates a "contact zone" [36, p. 173] between the source and target languages. High connectivity allows for a transfer devoid of moving original meaning boundaries, "low connectivity results in an increased hybridized discourse with many variants in the target language, leading to intercultural efforts of creations and shifts in meanings" [36, p. 173]. The role of legal translators is to "fix the semantic source, adjust it for the target language and-if necessary-build meta-linguistic devices to fill the conceptual gap for the target language" [36, $\mathrm{p}$. 178]. This goal can be achieved through a process Anne Wagner calls multivariable translational analyses in a third space. Their aim is to help understand in detail "concepts, their purposes, their assumptions, and their limitations in the source space" in order to "emphasize the similarities and/or differences in both the source and target spaces" [36, p. 183]. The recommended algorithm is

that (1) we examine some concepts, (2) process their variables and (3) search for the inter-correlations that the variables may possess in both the source and target spaces. Eventually, from this deciphering process provided by the inter-correlated variables, we could envisage the most appropriate translation [36, pp. 182-183].

In the following chapters, we adopt this procedure in order to conclude whether certain translation solutions "inherit the same legal usages or abuse (the trauma) the original framework" [36, pp. 175-176] or-in other words-in order to see if 
"original significances were preserved (heritage) or radically modified (trauma)" [36, p. 185]. We also follow in the footsteps of Aleksandra Matulewska, whowhile searching for sufficient equivalence between Polish and English insolvency terminology_adopted a related procedure: "Having established the meaning of selected terms, the comparison of Polish and English terminology was undertaken in order to discover to what extent they are convergent and divergent" [21, p. 171]. This knowledge is of crucial importance in making decisions on the suitability of terms.

\section{Land Registration in England and Wales}

The statutory definition of land can be found in the Law of Property Act 1925. According to it, "'land' includes land of any tenure, and mines and minerals, (...) buildings or parts of buildings (...) and other corporeal hereditaments; also (...) a rent and other incorporeal hereditaments, and an easement, right, privilege, or benefit in, over, or derived from land" [Section 205(1)(ix)]. Even this shortened definition-as can be seen-is very broad and covers both tangible (soil, buildings) and intangible components (rights). Corporeal hereditaments are physical objects connected with land (such as houses or timber) whereas incorporeal hereditaments are rights connected with it (such as easements).

Land registration in England and Wales is governed by the Land Registration Act 2002. The process of legislating on land registration in this jurisdiction started in 1862. The 2002 Act repealed and replaced its precursor, that is the Land Registration Act 1925 [17, p. 3].

As stated in the Explanatory Notes to the Land Registration Act 2002 (note 4),

the Crown is the only absolute owner of land in England and Wales: all others hold an estate in land. Estates, which derive from feudal terms of tenure, originally took many forms but were reduced by the Law of Property Act 1925 to two, an estate in fee simple absolute in possession, generally known as 'freehold'; and an estate for a term of years absolute[,] generally known as 'leasehold'. Apart from an estate, land may have the benefit of or be subject to other interests, which are rights and obligations relating to the land, belonging to the owner or to a third party.

In simple terms, freehold means "complete ownership of a building or land for an unlimited time" whereas leasehold is the legal right to use a building or piece of land for a period of time as arranged according to a lease. ${ }^{2}$ Freehold and leasehold are the most typical forms of land ownership. If one owns a freehold house (the majority of houses are freehold), they own the house and the land on which it stands

\footnotetext{
1 Longman dictionary of contemporary English online. https://www.ldoceonline.com/dictionary/freehold (accessed on 15 June 2020).

2 Adapted from Collins online English dictionary. https://www.collinsdictionary.com/dictionary/english/ leasehold (accessed on 15 June 2020).
} 
without any time limits. If one owns a leasehold flat (the majority of flats are leasehold), they own it for a certain number of years, as stated in the lease, without the land on which the flat stands. After the lease comes to an end, the flat returns to the landowner (the freeholder, the landlord). A leaseholder has to pay a freeholder service charges (charges for the services provided by the landlord, such as repairs to the building structure) and in most cases an annual ground rent for the land. The term of a lease is usually long: typically 99 or 125 years.

Commonhold, a new form of ownership, was introduced in 2004, but "very few commonholds have been created" since then. ${ }^{3}$ Commonhold "is particularly designed for flats and other forms of communal living type structures"4 although a commonhold can be a piece of land without any buildings, and it may include nonresidential units. A unit is "that part of the commonhold which is owned exclusively by the unit-holder on a freehold basis, usually a flat but a unit can also be a garage, a parking space, a garden, a shop, an office or even an unbuilt piece of land". 5 The rest of the commonhold is owned and managed jointly by the unit-holders through a commonhold association. The common parts are those parts that do not belong to particular units, for example, in the case of a block of flats, the lift, the stairs, the corridors or the car park. The commonhold association owns the freehold of the common parts. All unit-holders are members of the commonhold association, which is a company limited by guarantee. Each unit-holder has to contribute certain percentages to the running costs of the commonhold. The duties and obligations of the commonhold association and of each unit-holder are described in a commonhold community statement. Unit-holders vote at meetings of the commonhold association and in this way take decisions how the commonhold is run. ${ }^{6}$

In England and Wales, titles to land are registered by HM Land Registry. This is a non-ministerial government department, which "contains more than 25 million titles showing evidence of ownership for more than $87 \%$ of the land mass of England and Wales". 7

When a title is registered for the first time with HM Land Registry, a title register (register of title) is created. HM Land Registry allocates a unique title number to every registered title. The title register consists of three registers: the property register, the proprietorship register, and the charges register. As explained by HM Land Registry, ${ }^{8}$ the property register describes the property and the rights it benefits

\footnotetext{
3 The Law Society. Freehold, leasehold and commonhold. https://www.lawsociety.org.uk/public/forpublic-visitors/common-legal-issues/buying-a-home/freehold-leasehold-and-commonhold (accessed on 15 June 2020).

4 Wilsons Solicitors. Freehold. Leasehold. Commonhold. http://lawoffice.co.uk/commonhold.aspx (accessed on 15 June 2020).

5 Lease. The Leasehold Advisory Service. Unit. https://www.lease-advice.org/lease-glossary/unit/ (accessed on 15 June 2020).

${ }^{6}$ Lease. The Leasehold Advisory Service. Commonhold. https://www.lease-advice.org/advice-guide/ commonhold/ (accessed on 16 June 2020).

7 HM Land Registry. About us. https://www.gov.uk/government/organisations/land-registry/about\#whowe-are (accessed on 15 June 2020).

${ }^{8}$ HM Land Registry. Glossary. https://eservices.landregistry.gov.uk/eservices/FindAProperty/view/Info. do?page=glossary_one\&id=p_glossary_link (accessed on 16 June 2020).
} 
from, the proprietorship register informs about the owner of the property and any restrictions that limit their power to deal with it, and the charges register provides information on mortgages or rights adversely affecting the property. The register is accompanied by a title plan, which is a map showing the general boundaries of a registered title.

\section{Land Registration in Scotland}

Under section 113 of Land Registration etc. (Scotland) Act 2012, land includes "buildings and other structures", "the seabed of the territorial sea of the United Kingdom adjacent to Scotland", and "other land covered with water".

Titles to land are registered with the Registers of Scotland, a non-ministerial department of the Scottish Government. It holds 20 public registers, and among them the Land Register of Scotland is the main register. Another one is the General Register of Sasines (the Sasine Register), a register of title deeds dating back to 1617. It is being gradually replaced by the Land Register of Scotland and is due to close in 2024.

Registration in the Land Register of Scotland results in the creation of a title sheet. According to the information on the Registers of Scotland's website, ${ }^{9}$ a title sheet contains four sections along with a unique title number. The property section describes the property and any rights associated with it. The proprietorship section informs about the current registered proprietor. The securities section provides details of any mortgages relating to the property. Finally, the burdens section contains information on the property owner's obligations, for example building and maintaining boundary walls. A title sheet is accompanied by a title plan. This document shows property boundaries.

Under Scots law, the term "freehold" has no real meaning, and if it is used, it is done for convenience. ${ }^{10}$ Freehold's broad equivalent is "a heritable title", ${ }^{11}$ which means absolute/outright ownership. Currently, nearly all property is held under this type of tenure, including apartments and tenements. ${ }^{12}$ As to leasehold, the Scottish parliament virtually ended it, and today only isolated cases of leasehold properties remain. ${ }^{13}$ There is no equivalent to commonhold in Scotland; ${ }^{14}$ however, although "commonhold is a system unique to England and Wales", "many civil jurisdictions

\footnotetext{
${ }^{9}$ Registers of Scotland. Title documents. https://www.ros.gov.uk/services/order-documents/what-title -documents-can-tell-you (accessed on 17 June 2020).

${ }^{10}$ Shepherd and Wedderburn. Your guide to English and Scottish property law terms. https://shepwedd. com/sites/default/files/Your_Guide_to_English_and_Scottish_Property_Law_Terms_Scots_Counsel.pdf (accessed on 17 June 2020).

11 Ibidem.

12 Jim Gibson. Leaseholds ban proposal-the facts. https://homereportscotland.scot/leaseholds-outrightownership-facts/ (accessed on 17 June 2020).

13 Ibidem.

14 Joanne Wilson. 2015. The legal differences across Hadrian's Wall. https://www.morton-fraser.com/ knowledge-hub/legal-differences-across-hadrians-wall (accessed on 17 June 2020).
} 
also have systems along similar lines to commonhold. Scotland for example has the tenement system" [2, p. 4].

Tenements-according to the Scottish Government's website-account for more than a quarter of the housing stock in Scotland and take many forms. Most of them are residential blocks. However, office blocks and large houses divided into flats also fall within this category. ${ }^{15}$

Under the Tenements (Scotland) Act 2004, a tenement

means a building or a part of a building which comprises two related flats which, or more than two such flats at least two of which (a) are, or are designed to be, in separate ownership; and (b) are divided from each other horizontally, and, except where the context otherwise requires, includes the solum and any other land pertaining to that building or, as the case may be, part of the building; and the expression 'tenement building' shall be construed accordingly [section 26(1)].

As explained by the law firm TC Young Solicitors, the information on which parts of a tenement are owned in common, which parts of a tenement the owners of properties in it are responsible for maintaining and in what share, how a tenement building is managed, and how tenement decisions are taken and carried out should be included in title deeds. If they have all of this information, this information is clear, and the title deeds of all other properties in a tenement are consistent in this respect, then the title provisions are authoritative. Otherwise the Tenements (Scotland) Act 2004 stipulates the rights and obligations of tenement property owners through a default scheme for the maintenance and management of tenements - the Tenement Management Scheme. ${ }^{16}$ It "fills in the gaps in title deeds and helps make flat owners' responsibilities more clear". ${ }^{17}$

\section{Land Registration in Northern Ireland}

In Northern Ireland, titles to land are registered in the Land Registry, which is held by Land \& Property Services, a part of the Department of Finance. Each title receives a unique folio number, a folio being the equivalent of a title register in England and Wales. Land Registry Service defines a folio as an official document describing briefly the registered property, providing details of its ownership, and informing about any other matters affecting it, such as rights of way, mortgages, etc. ${ }^{18}$ Apart from a folio, a Land Registry map is produced (title

\footnotetext{
15 Scottish Government. Tenements. https://www2.gov.scot/Topics/Justice/law/17975/11023 (accessed on 18 June 2020).

16 TC Young Solicitors. Tenement repairs - a common problem. https://www.tcyoung.co.uk/our-blog/ tenement-repairs-common-problem (accessed on 18 June 2020).

17 mygov.scot. Tenement management scheme. https://www.mygov.scot/common-area-repairs/tenementmanagement-scheme/ (accessed on 18 June 2020).

18 Land Registry Service. What is a folio? https://landregistryservice.co.uk/index.php?page=faq\&id=56 (accessed on 18 June 2020).
} 
plan equivalent), "showing the location and extent of the land or property's legal boundary". 19

Another register held by Land \& Property Services is called the Registry of Deeds. It contains information about land not registered in the Land Registry. ${ }^{20}$ Under this system, a written summary (a memorial) of the document transferring ownership is prepared, lodged in the Registry of Deeds with the original document, and kept by the Registry of Deeds as an ownership record while the original transfer document is returned to the person who lodged it. ${ }^{21}$ However, the Registry of Deeds does not guarantee the validity of registered documents or their legal effect, ${ }^{22}$ sounlike with the Land Registry-there is no government guarantee of title. The ongoing migration of titles to land from the Registry of Deeds to the Land Registry will result in the phasing out of the Registry of Deeds. ${ }^{23}$

As to land ownership forms in Northern Ireland, Brice Dickson [10, p. 293] enumerates the following ones:

- “an 'estate' in land called a 'freehold estate' or a 'fee simple absolute' "—in practice tantamount to owning land outright,

- fee tail-land is held by one person until this person's death, upon which "it passes automatically to that person's oldest child",

- life estate- "land is held by one person (a 'life tenant') for as long as he or she lives but reverts to the fee simple owner when the life tenant dies",

- leasehold estate-renting (leasing) land from somebody else, typically for a fixed period, which might be renewed; the rent payer is called a "tenant" (or a "lessee"), and the land renting person-a "landlord" (or a "lessor"),

- fee-farm grant-similar to a fee simple absolute, but an annual rent needs to be paid to the freeholder.

Currently_explains Brice Dickson [10, p. 293] —all of the above forms of land ownership "are different types of property rights in land".

\section{Land Registration in Ireland}

Under section 3 of the Land and Conveyancing Law Reform Act 2009, land includes

\footnotetext{
19 nidirect. How to find property and land information. https://www.nidirect.gov.uk/articles/how-findproperty-and-land-information (accessed on 19 June 2020).

20 nidirect. Searching the Registry of Deeds. https://www.nidirect.gov.uk/articles/searching-the-registryof-deeds (accessed on 19 June 2020).

21 Campbell \& Haughey Solicitors Ltd. Conveyancing (transfer of land) in Northern Ireland. https:// www.ch-solicitors.com/conveyancing-transfer-land-northern-ireland/.nidirect. Searching the Registry of Deeds. https://www.nidirect.gov.uk/articles/searching-the-registry-of-deeds (accessed on 19 June 2020).

22 nidirect. Searching the Registry of Deeds. https://www.nidirect.gov.uk/articles/searching-the-registryof-deeds (accessed on 19 June 2020).

23 Department of Finance. Registry of Deeds. https://www.finance-ni.gov.uk/topics/land-registration/ registry-deeds (accessed on 19 June 2020).
} 
(a) any estate or interest in or over land, whether corporeal or incorporeal, (b) mines, minerals and other substances in the substratum below the surface (...), (c) land covered by water, (d) buildings or structures of any kind on land and any part of them (...), (e) the airspace above the surface of land or above any building or structure on land which is capable of being or was previously occupied by a building or structure and any part of such airspace (...), (f) any part of land.

In Ireland, registration of title to land falls within the ambit of the Property Registration Authority. It manages the Land Registry, where titles are registered. The deeds are submitted to the Registry, and on their basis folios are prepared. They contain information on the property and its ownership. Folios are accompanied by Land Registry maps. Both folios (title register equivalents) and maps (title plan equivalents) have electronic form. The Property Registration Authority also manages the Registry of Deeds. Its main aim is to record "the existence of deeds and conveyances affecting unregistered property". It is not obligatory under law to register a document, but registered deeds have precedence over unregistered registerable deeds. Moreover, the system sorts out priorities between registered documents concerning the same piece of land. A deed lodged in the Registry of Deeds has to be accompanied by a ROD Application Form (previously called a Memorial). The form summarizes the relevant details of the deed. After completing the application procedure, the deed is not kept in the Registry, but the lodging party receives it back. The ROD Application Form is retained as a record. It is worth remembering that the Registry of Deeds does not interpret deeds, nor does it provide any guarantee that they are effective, it only records their existence. ${ }^{24}$

A folio is conclusive proof of ownership and "any right, privilege, appurtenance or burden appearing thereon". ${ }^{25}$ It consists of three parts: Part I-Description of the Property, Part II-Ownership, Part III-Burdens and Notices of Burdens. An accompanying map "shows the approximate position of the general boundaries of the property in red, in relation to the surrounding properties" [29, p. 43].

In Ireland, land ownership takes two forms: it is either freehold or leasehold. "Freehold means the owner has absolute right over the land and any buildings on the land. There is no time limit on the ownership. When the owner disposes of the freehold the new owner has absolute right over the land and any buildings on the land" $[25$, p. 4]. Leasehold "gives an exclusive right of possession of land to the tenant for a period, in return for rent". ${ }^{26}$ Before the enactment of the 2009 Act, other forms of ownership could be created, such as "fee tail estate" or "fee farm grant". 27

\footnotetext{
24 The paragraph utilizes the information from the website https://www.prai.ie/the-property-registrati on-authority/PropertyRegistrationAuthority. The Property Registration Authority (accessed on 20 June 2020).

25 Property Registration Authority. Land Registry Services. https://www.prai.ie/land-registry-services/ (accessed on 20 June 2020).

26 McMahon Legal. Leasehold interests. http://mcmahonsolicitors.ie/property-ownership-leases/ (accessed on 21 June 2020).

27 Kieran Coughlan. 2014. Land ownership now comes in two forms. The Irish Examiner. https://www.
} 
Land may be also owned solely or may be co-owned. The two types of co-ownership are joint tenancy and tenancy in common. As Kieran Coughlan explains, the names "can create confusion; for simplicity, (...) [the concept] would be better understood if these were described as joint ownership or ownership in common, given that neither version involves tenants, under the normal meaning of the word". ${ }^{28}$ In the case of a tenancy in common each owner has "a distinct share which can be succeeded to on the owner's death. The key feature of a joint tenancy is the right of survivorship, whereby on the death of one joint tenant, the deceased owner's interest ceases and the land becomes vested in the surviving joint tenant(s)". ${ }^{29}$

\section{Land Registration in the USA}

In the USA - as Christina Braisted Rogers states - titles to land do not have to be recorded. However, they might be, and each state's county has its own recording office. Recordation protects against third-party claims. "All the US jurisdictions operate a system of deeds registration" [8, p. 6]. There is no state guarantee of title. A register of deeds is "a constantly updated archive of documents which describe rights to real property, indexed by names of the participants in these transactions, the geographical locations of the properties affected and other characteristics of transactions" [30, p. 3]. Before completion of any sale transaction,

the person intending to acquire an interest in land is responsible to trace the seller's legal right to sell back in time through preceding transactions documented by archived deeds to a 'good root of title' as evidenced by properly documented transactions. The search must also identify any other transaction recorded in the Register of Deeds, such as mortgages, liens, powers of attorney, and other documented potential interests in a property, which affect the conveyance of clear title or interest in the property. This search must be repeated each time that a transaction occurs which affects rights to a particular property, to assure the person who wishes to acquire a right to a property that the seller of that right can effect the transaction and that there is no 'cloud' on the title being conveyed" [30, p. 3].

In the context of recordation, there are three systems of taking priority by deeds: race systems, notice systems, and race-notice systems. In race systems, the order of recordation is the decisive factor: the deed recorded first has priority (for instance, if

\footnotetext{
Footnote 27 (continued)

irishexaminer.com/farming/finance/land-ownership-now-comes-in-two-forms-265602.html (accessed on 21 June 2020).

28 Ibidem.

29 Homs Solicitors. The Land and Conveyancing Law Reform Act 2009: An overview. https://www. homs.ie/publications/the-land-and-conveyancing-law-reform-act-2009-an-overview/ (accessed on 21 June 2020).

${ }^{30}$ Christina Braisted Rogers. 2019. USA: Real estate laws and regulations 2020. https://iclg.com/pract ice-areas/real-estate-laws-and-regulations/usa (accessed on 21 June 2020).
} 
a piece of land has been sold twice by the same seller). In notice systems, a subsequent deed has priority if the purchaser is unaware (has no notice) of an earlier deed. In race-notice systems, a subsequent deed has priority if the purchaser is unaware of an earlier deed and records the subsequent deed before the earlier purchaser. It must be remembered that "a properly recorded deed provides constructive notice of its contents, which means that all parties concerned are considered to have notice of the deed whether or not they actually saw it". ${ }^{31}$

The recording process consists in presenting a deed to the relevant office in the county where the property is situated. The document is duplicated and its copy included in the book of official records. After the original deed has been duplicated, recorded, and filed in the recorder's office, it is given back to the owner. ${ }^{32}$

As Elizabeth Cooke explains, two solutions have been worked out in order to overcome two drawbacks of title recording systems: their cumbersomeness and inability to be comprehensive. Firstly, abstract companies search the registries providing information about titles. Secondly, one can insure title, "whereby the risk of undiscoverable interests can be met by insurance" [8, p. 6]. The role of an abstract company is to prepare an abstract of title, which contains a full history of the real estate and also shows any unpaid taxes, outstanding mortgages, unpaid judgments, or unsatisfied liens against the property [1, p. 513].

\section{Land Registration in Germany}

The German system of title registers ${ }^{33}$-as Paweł Blajer states [5, p. 72] in his extensive article on the history of title registers in German-speaking countriesgoes back to the late Middle Ages. The first title registers were created in Cologne around 1135 . They provided basic information on the legal status of a real property. Investigating the history of title registers in Germany, Paweł Blajer comes to the conclusion that a unitary system of title registers in Germany appeared only after an all-German Civil Code (Bürgerliches Gesetzbuch-BGB) had been formulated. The unitary system's foundations were laid by the Act of 8 March 1897 on Title Registers (Grundbuchordnung), which — after many amendments- has been in force up to the present day. It is worth remembering that substantive law issues relating to title registers are addressed in the German Civil Code $(B G B)$, and procedural law issues-in the Act on Title Registers $(G B O)$.

The term real property refers to built-on and unbuilt-on land and rights equivalent to land titles (grundstücksgleiche Rechte). Carl Creifelds defines [9, p. 606] a plot of land (Grundstück) as each separate part of the Earth's surface registered in a separate title register. Article 905 of the $B G B$ states that "the right of the owner

\footnotetext{
31 Law library-American law and legal information. Deed. Recording. https://law.jrank.org/pages/6018/ Deed-Recording.html (accessed on 25 June 2020).

32 The process description based on: ibidem.

33 In German-speaking countries, title registers are called Grundbücher. This is a compound noun which translated literally into Polish means land books.
} 
of a plot of land extends to the space above the surface and to the subsoil under the surface". ${ }^{34}$ Rights equivalent to land titles, for example permanent residential rights (Dauerwohnrechte) or heritable building rights (Erbbaurechte), are described as such because under the $B G B$ the real property regulations are applicable to them.

Title registers contain information about real properties, rights equivalent to land titles, real property owners, as well as burdens affecting real properties and rights attached to them. Each owner may request an abstract of a title register for their property; however, persons not being owners (for instance lenders, creditors) must demonstrate that they have a legitimate interest in gaining access to the content of a given title register. The owner of a real property may also authorize a third party to inspect a title register.

Title registers in Germany are kept by federal states. This is the task of offices for title registers (Grundbuchämter) at district courts (Amtsgerichte). A key role in the title registration procedure is played by a court referendary (Rechtspfleger). Unlike in Poland, a central directory of title registers does not exist in Germany. It is also not possible to gain online access to title registers. In 1993, an electronic title register, based on scanned documents, was introduced, and an electronic title registration procedure has been an option since 2009 .

Apart from title registers, there are in Germany - as they are in Poland-registers of land and buildings called cadastres (Liegenschaftskataster). Such cadastres are kept by cadastral offices in federal states. Both systems-as Irena Kleniewska rightly states [15, pp. 12-13]—contain similar data. Title registers are more focused on rights and burdens connected with real properties whereas cadastres-on physical features of real properties, such as their location, shape, size, and the way they are used.

The $B G B$ contains several fundamental rules governing the system of title registers in Germany. Below, there is a list of them [5, p. 85]:

- Registration principle (Eintragungsprinzip) - in order to transfer ownership of a real property or to encumber it with a right, an entry in a title register is necessary (article 873 of the $B G B$ ),

- Statutory presumption principle (gesetzliche Vermutung) — a statutory presumption (article 891 of the $B G B$ ) that a right entered in a title register in favour of a person is this person's right and that a right deleted from a title register does not exist,

- Good faith principle (Gutglaubenswirkung) — it breaches the rule nemo plus iuris ad alium transferre potest quam ipse habet and makes it possible to acquire a right to a real property from an unauthorized person if this person is entered in a title register as the right holder (article 892 of the $B G B$ ),

- Detailed description principle (Spezialitätsprinzip)—understood as a requirement that limited property rights should encumber only specific real properties and requiring detailed descriptions of those rights (in particular mortgages) in title registers,

${ }^{34}$ German Civil Code $B G B$. https://www.gesetze-im-internet.de/englisch_bgb/ (accessed on 20.08.2020). 
- Priority principle (Prioritätsprinzip) — it determines the order of priority of rights entered in a title register (article 879 of the $B G B$ ).

Under the $G B O$, each title register consists of an introductory part, an inventory, and three sections. An introductory part contains the name of an office for title registers at an appropriate district court, the name of a registration district, and a volume and title register number. An inventory includes a detailed description of a real property (its location and size in accordance with cadastral data and the way it is used), a list of rights connected with it (for instance easements, if any), and also its "history", that is information about parts connected to it and disconnected from it. In the first section, there are entries about former and current owners together with the sizes of their shares in the case of co-ownership. The second section provides information on all non-monetary burdens and disposal limitations (for instance pre-emptive rights), and the third section - on all monetary burdens (for instance mortgages or land debts). All deleted (invalid) entries are underlined in red (or in black in the case of a copy). Those deleted entries refer to, for instance, former owners, cancelled land debts, or property size corrections.

Abstracts or copies of title registers are issued by offices for title registers and additionally_-since 1 September 2013-by civil-law notaries.

\section{Land Registration in Austria}

The basic concepts underlying German title registers have been implemented into Austrian law. However, as Paweł Blajer states [5 p. 93], "the historical development of title registers was slightly different than in Germany, resulting in characteristic, independent solutions". ${ }^{35}$ In his opinion, title registers in Austria were modelled on Czech land books (Landtafeln), going back to the 13th century [5, p. 94]. In those books, entries were recorded in chronological order first in Latin and from 1627 also in German. They were also called books of instruments (Instrumentenbücher) because important excerpts from source documents were copied into them. In the 18 th century, they were converted into title registers. The structure and function of those title registers is mirrored by today's title registers. Consequently, Austria is perceived as the first country in the world having title registers with all real property rights recorded in them [5, p. 95].

An Austrian title register, which is closely connected with a cadastre, comprises a main register (Hauptbuch) and a register of instruments (Instrumentenbuch), also called an auxiliary register (Hilfsbuch) or a collection of deeds (Urkundensammlung). A main register contains a description of a real property, informs about its owner, and lists all burdens and rights. An auxiliary register is a collection of source deeds constituting the basis for making entries in a main register. A main register consists of an inventory sheet (Gutsbestandsblatt), which forms the register's first section (A-Blatt). It comprises two parts: A1-Blatt

\footnotetext{
$\overline{35}$ Translated by J.G. and A.D.K.
} 
informs about the size of a real property, its type, and the way it is used (the data here come from the cadastre); A2-Blatt lists rights attached to the ownership of a real property (for instance easements) and the property-related changes (for instance informs about parts connected to it and disconnected from it). The second section (B-Blatt) provides information on the owner or co-owners of a real property (in the case of co-ownership percentage shares are also given). Moreover, in this section, the priority of property rights and their limitations are recorded (for instance nonage or bankruptcy of a real property owner). The third section $(C$-Blatt) shows first and foremost burdens affecting a real property (for instance easements and liens) and limitations on its disposal (for instance a prohibition on its sale, a pre-emptive right, a buy-back right). Irena Kleniewska $[15$, p. 11] specifies that under the Austrian title register system, title registers are kept for cadastral units (Katastralgemeinden) at district courts (Bezirksgerichte) by court referendaries (Rechtspfleger), who act under the supervision of judges. Irena Kleniewska adds that Austrian title registers conform to the rule of their formal and substantive openness and to the rule of their reliability. Furthermore, an entry regarding the transfer of real property ownership is obligatory and constitutive [15, p. 11].

It is worth mentioning that there are still special registers of land in Austria, such as a register of railroad land (Eisenbahnbuch) or a register of mining land (Bergbuch), although no entries are made in them any more. In Styria for instance, its register of railroad land is the only source of knowledge on public real properties.

The current system of title registers operates on the basis of the 1955 General Act on Title Registers (Allgemeines Grundbuchsgesetz) and the boundary cadastre (Grenzkataster), which enables a reliable determination of the boundaries of a specific real property. The General Civil Code (Allgemeines Bürgerliches Gesetzbuch) is the fundamental statute governing the acquisition of ownership and other property rights as well as the use of real properties as security for debts.

Electronic title registers were introduced in Austria in 1980 in the form of a computer database. Civil-law notaries and barristers, among others, have direct access to this database. It provides reliable information on ownership rights, mortgages, easements, and other rights and burdens connected with real properties. It is supplemented by an electronic land plot database (Grundstücksdatenbank), which - apart from title register data-provides essential information from the Austrian cadastre.

A title register is a public document which-unlike in Germany-may be accessed by any person (even without a legitimate interest). Consequently, courts do not need to issue copies or abstracts of title registers unless it is necessary to inspect a document on the basis of which an entry in a given title register was made. 


\section{Land Registration in Switzerland}

Paweł Blajer's legal history research has led him to the conclusion [5, p. 101] that the system of title registers developed in the Swiss Confederation only in the 19th century at first in the cantons of Basel-City (1860), Solothurn (1873), and Vaud (1882). Federal title registers (eidgenössische Grundbücher) were created under the 1907 Civil Code, which governed both substantive and procedural issues relating to title register entries.

Swiss title registers are state registers. All real properties together with attached rights and burdens (for instance ownership rights, easements, and mortgages) are recorded in them. Rights and burdens are created, changed, transferred, and cancelled by virtue of an appropriate entry in a title register. Title registers are kept on identical federal forms under a system in which each real property has a main register. Title registers are open to the public and provide the guarantee of title on condition that a real property has been acquired in good faith. An entry in a title register is constitutive.

Currently, title registers are kept in electronic form. Each title register comprises a journal (Tagebuch), a main register (Hauptbuch), title plans (Grundstückspläne), source documents (Belege), and an auxiliary register (Hilfsregister). A journal contains applications for making an entry in a title register in order of their receipt. In a main register, one can find chronological data on the acquisition or sale of a real property, a description of buildings located on it, and information about rights and burdens attached to it. Title plans provide geodetic information on a given real property, and a collection of source documents includes for instance contracts of sale or easement agreements relating to it. An auxiliary register lists owners and creditors. Irena Kleniewska states [15, p. 10] that every person concerned may request that the content of a title register be made compliant with the actual situation or may file an application for correcting an entry.

In Switzerland, there is no central office for title registers. Title registers are kept by offices for title registers (Grundbuchämter) in particular cantons. The offices are headed by title register administrators (Grundbuchverwalter). In some cantons there is only one office of the kind per canton whereas in other cantons such an office may cover one commune only or a few of them. For instance, in the canton of Zurich there are several offices for title registers.

As the Swiss title register system is based on the principle of general access, any person may find out who the owner of a real property is and what easements and burdens are attached to it without the necessity of demonstrating any entitlements to this information. Furthermore, any person who shows a legitimate interest may obtain detailed information from a title register and request its abstract. Cantonal authorities are also permitted to publish unclassified information on the acquisition of real properties in cantonal official journals. 


\section{Land Registration in Poland}

In the Polish Civil Code the term real property (real estate, immovable property) is defined in the following manner: "Real properties shall be understood as parts of the Earth's surface in separate ownership (land) and buildings permanently fixed to the land or parts of such buildings if under special regulations they are owned independently of the land" 36 [article 46(1)].

As Ryszard Strzelczyk states [31, pp. 3-4], the term real property covers:

(a) Unbuilt-on land,

(b) Built-on land (land with a building permanently fixed to it, which means that any attempt at separating the building from the land would result in the destruction of or the damage to the building; as a consequence, a shed, for instance, not permanently fixed to the land does not convert unbuilt-on land into built-on land),

(c) A building permanently fixed to the land if under special regulations the building is owned independently of the land (the owner of the building is not the owner of the land; for instance, a building built on land held under a long-term lease. In this case, the owner of the land is the state or a local government unit, such as a commune, and the owner of the building - the land's long-term lessee/ leaseholder),

(d) A separated part (a residential or non-residential unit) of a building permanently fixed to the land if under special regulations the unit is owned independently of the land (the owner of the unit is not the owner of the land $;{ }^{37}$ the special regulations in question are contained in the Act of 24 June 1994 on the Ownership of Residential and Non-Residential Units. Under them, a building may be divided into residential or non-residential units held in separate ownership. Each of such residential and non-residential units is a separate real property, and a separate title register is created for each of them.

To sum up, there are three types of real properties: land (unbuilt-on and built-on land-letter a and $\mathrm{b}$ above), buildings (letter $\mathrm{c}$ above), and residential and non-residential units (letter $\mathrm{d}$ above).

In Poland, apart from the right of ownership, there is also a cooperative property right to a residential or non-residential unit although it cannot be granted any more (this possibility was repealed in 2007). If we have this right, we can use a residential or non-residential unit, redecorate it, improve its condition, or derive profit from it. This right can be sold, gifted, left in a will, or burdened with a mortgage. However, we do not own such a unit. It is owned by a housing cooperative together with the land on which the building stands (the land may be also held by a housing

\footnotetext{
36 Translated by J.G. and A.D.K.

37 The owner of the unit is obligatorily the co-owner of the building's common parts and the land on which the building stands or the co-owner of the building's common parts and the long-term co-lessee of the land on which the building stands if the land is held under a long-term lease.
} 
cooperative under a long-term lease). There is no need to create a title register for the right in question, but a title register may be created for it. A cooperative property right to a residential or non-residential unit may be converted into the right of ownership.

The registration of titles to real properties is governed by the Act of 6 July 1982 on Title Registers and Mortgages. Under this statute, titles to real properties are recorded in title registers. Title registers are open to the public, and lack of knowledge of their content or applications mentioned in them cannot be used as an excuse. It is assumed that a right entered in a title register mirrors the real property's actual legal status. If its legal status entered in a title register is inconsistent with the real property's actual legal status, the content of the title register prevails in favour of a person who through a legal transaction with an authorized person as evidenced by the title register has acquired ownership or another property right (the guarantee of title). There are, however, certain restrictions with regard to the guarantee of title. First of all, there is no guarantee of title when no valuable consideration has been given for the property right (for instance in the case of gift) or when the purchaser acts in bad faith. A person acts in bad faith if the person knows that a title register's content is inconsistent with the actual legal status or if the person could have easily found that out. Other restrictions include, for instance, utility easements or right of way easements. ${ }^{38}$ This means in practice that unregistered utility or right of way easements still burden the real property to which they refer after its transfer.

Title registers are kept by district courts (the lowest courts in Poland). Unless special regulations provide otherwise, a separate title register is kept for each real property. This provision also refers to residential and non-residential units and real properties divided into residential and non-residential units. In a title register for a building with residential or non-residential units in separate ownership, a contractually specified method of managing the building is recorded; if there is no record to that effect, it is assumed that the management method is based on applicable legislation.

A title register consists of four sections:

(1) The first section contains a description and location of the real property and rights attached to its ownership,

(2) The second section informs about owners and long-term lessees,

(3) The third section provides information about restrictions and burdens affecting the real property, except for mortgages,

(4) The fourth section is intended for registering mortgages.

A title register for a cooperative property right to a residential or non-residential unit consists of four sections:

\footnotetext{
${ }^{38}$ Up to this point, the paragraph is based on Chapter 1 of the Act of 6 July 1982 on Title Registers and Mortgages.
} 
(1) The first section contains a description and location of a residential or nonresidential unit and location of the real property with which it is connected,

(2) The second section informs about the person who has a cooperative property right to a residential or non-residential unit,

(3) The third section provides information about restrictions and burdens affecting the right, except for mortgages,

(4) The fourth section is intended for registering mortgages.

Title registers are created and kept in electronic form. Every title register is accompanied by a title register's file. A file contains documents and letters concerning the real property. Files are kept in courts. Any person who knows the number of a title register may browse the title register free of charge online.

The Minister of Justice maintains a central electronic database of title registers. It contains title registers for the whole country. The Minister of Justice is responsible for the safety of the database, in particular for protecting it from unauthorized access of third parties, destruction, and data loss. Information from the central database of title registers is provided by the Central Information Office for Title Registers. It has branches at divisions for title registers in district courts. The Central Information Office issues, on request, copies of title registers and abstracts of them. Such copies and abstracts have the legal effect of court issued documents.

The owner of a real property is obliged to immediately submit an application for registering their right of ownership in a title register. If a third party suffers a loss as a result of not registering the right of ownership in a title register, the owner is liable for the loss when it stems from not submitting an application or delaying its submission. ${ }^{39}$

\section{In Search of Equivalents-A Theoretical Background}

The aim of the above descriptions of land registration systems in various jurisdictions (England and Wales, Scotland, Northern Ireland, Ireland, the USA, Germany, Austria, Switzerland, and Poland) has been to create a third space, a space where selected aspects of selected legal systems will mingle revealing more or less clear similarities and more or less distinct differences between them. The third space brought into being occupies an intermediate place between an input point and an output point. In our case, the input point is formed by the Polish legal system (specifically its land registration system) and the Polish language, serving as a means of expressing it, and the output point is formed by the English and German languages, in which we want to render certain concepts of Polish law, and selected legal systems using the English and German languages as a means of expression. Those systems are treated as points of reference. Our third space is fed by legal concepts flowing from selected directions. There, legal concepts belonging to various jurisdictions

\footnotetext{
39 The six paragraphs above are based on Chapter 2 of the Act of 6 July 1982 on Title Registers and Mortgages.
} 
mix with each other either keeping their separateness or overlapping to a greater or lesser extent. This process of forming more or less distinct conceptual doublets, triplets, quadruplets, etc. or of not being able to forge any bonds by concepts occurs in the consciousness of a translator, where a third space resides. From it, translation equivalents emerge either as linguistic structures directly taken over from one jurisdiction or as linguistic structures newly coined to suit the unfamiliar demands of a source term. A third space is a place where what is alien may be recognized as such and accordingly dealt with and what is common may be found and made use of.

\section{In Search of Equivalents-Practical Solutions}

The encounters of legal concepts coming from various jurisdictions (at least two) in a third space culminate in the most suitable translation suggestions so as to introduce-let us reiterate_- "foreign legal worldviews into a different legal life-world" and "make the foreign legal text accessible for recipients with a different (legal) background" [24, p. 283]. Below we can observe the results of the passage through a third space.

\section{A Księga wieczysta}

In the context of the Polish land registration system, one of the most important terms is ksiega wieczysta (literally perpetual/eternal book). The name is misleading as it is neither a book nor is it, obviously, perpetual or eternal. This odd turn of phrase is to suggest the document's relative permanence against the passage of time. In the process of translation it is then necessary to forget about the term's literal meaning and focus instead on its function. Functionally, ksiega wieczysta is an official register kept to provide information on a real property's legal status. As such, it has several functional equivalents within the English language jurisdictions described: a title register/register of title (England and Wales), a title sheet (Scotland), and a folio (Northern Ireland and Ireland). In the USA, the system of official land registers of the type similar to ksiega wieczysta exists in vestigial form and on a voluntary basis: from this perspective the term in question might be equated with a certificate of title. $^{40}$

The term ksiega wieczysta is often translated into English as land and mortgage register (cf. [22, p. 176]; [35, p. 42]; [34, p. 115]; the translation of the Act of 6 July 1982 on Title Registers and Mortgages by Centrum Tłumaczeń PWN.PL [PWN.PL Translation Centre]-hereinafter referred to as the PWN.PL translation or [33]). Other translation options are land register $[16,37 ; 16, \mathrm{p} .186]$ and register of deeds [16, p. 186]. Despite the popularity of the first translation, it is not the best one. Its acceptability stems from the fact that mortgages are indeed registered in the documents in question. However, mortgages are not the only burdens registered in them,

\footnotetext{
${ }^{40} \mathrm{Cf}$. Law library-American law and legal information. Registration of land titles. https://law.jrank .org/pages/9730/Registration-Land-Titles.html (accessed on 3 July 2020).
} 
so there is no need to single them out. A better option is land register, but in Poland it is possible to create a register that is not related to any land (cooperative property right to a residential or non-residential unit). Finally, register of deeds is definitely wrong because ksiegga wieczysta is not a register of title documents but a register of title. It would also be wrong to render the term in question in a literal manner: this would generate a legally meaningless phrase. Consequently, the functional equivalents mentioned above ought to be preferred translation options as they convey the concept of księga wieczysta in a natural, undistorted, and readily understandable manner.

The prevalent German equivalent for the term is the compound Grundbuch, literally land book (for instance [4, p. 49]; [3, p. 135]; [14, p. 216]). Translators utilize the term used in all German-speaking countries to denote a very similar institution, which allows for the preservation of the original meaning to a significant degree. The same translation strategy is not always followed when translating into Polish. For instance, Paweł Blajer [5, p. 65] calques the German compound Grundbuch, arriving at the term ksiega gruntowa, instead of using the contextually typical Polish phrase księga wieczysta.

\section{B Użytkowanie wieczyste}

Another misleading term, this time partially misleading, is użytkowanie wieczyste. Under Polish law, użytkowanie wieczyste is a specific type of property right, located between ownership and limited property rights. It refers exclusively to land (ground only) that is owned by the state or local government units. Such land might be transferred for use to a natural or legal person. The transfer must be made by deed (drafted and certified by a civil-law notary) and registered in a title register. The transferee may use the land to the exclusion of third parties. The right to use the land may be sold, inherited, or burdened with a mortgage. The land may be transferred for use for a period not shorter than 40 years and not longer than 99 years, which period may be extended for another period between 40 and 99 years. The transferee is entitled to use the land in any way that does not infringe legislation, the principles of community life, and a land transfer agreement. The land use is not free of charge: the transferee has to pay a one-time fee and an annual fee.

The term's misleading nature mentioned above is related to the adjective wieczyste (literally perpetual, eternal). As we have seen, the right to use (użytkowanie) is neither perpetual nor eternal but just (relatively) very long. Polish translators tend to render the term in English as perpetual usufruct ([35, p. 39]; [34, p. 109]; [22, p. 519]; [33]). The phrase sounds peculiar and does not ring any (or at least many) bells with lawyers operating within English language legal systems (maybe apart from associations with Poland). The Polish term has, however, a close companion in for instance English law: a lease. The word might be (as leases are typically long-term) supplemented with the adjective long-term as an equivalent of the adjective wieczysty and to emphasize the lease's duration. This solution was employed by Roman Kozierkiewicz, whose English version of użytkowanie wieczyste is long-term lease [16, p. 563]. Alternatively, a phrase utilizing concepts 
taken from English language legal systems might be coined in order to account for all specific features of the Polish term-state or local government ground long-term lease. In a likewise fashion, uzytkownik wieczysty, that is a person who has a leasehold interest, is long-term lessee or long-term leaseholder rather than perpetual usufructuary. What comes as a surprise is that the same translator (Roman Kozierkiewicz) who used the term long-term lease for użytkowanie wieczyste renders użytkownik wieczysty as perpetual user [16, p. 563], by that token breaking two rules: the consistency rule and the naturalness rule.

Polish-German translators encounter serious difficulties in rendering the analysed term. The difficulties may be attributed first and foremost to being unaware of the differences between the concept of uzytkowanie wieczyste in Poland and in German-speaking countries. In the specialist dictionary by Alina Kilian and Agnieszka Kilian under the entry in question [14, p. 509] one can find the following helpful note: the Polish term ewiger Nießbrauch (literal translation of użytkowanie wieczyste) may be translated as Erbbaurecht because this German term with regard to its function and legal consequences is close to the Polish phrase użytkowanie wieczyste. Erbbaurecht (literally heritable building right) is a functional equivalent, also employed in the dictionary edited by Bogusław Banaszak [3, p. 432] and in a slightly modified form-Erbbau-used by Marcin Zaremba [38, p. 142]. Another option is to utilize a term directed at the source language legal culture, that is Polish law: Erbnießbrauch (literally heritable right to use). This option has been exercised by Dariusz Łubowski [23, p. 273]. The dictionary edited by Ludwik Bar [4, p. 172] creates, unfortunately, considerable confusion as it provides several terms without any explanations as to their usage, thus leaving a translator at a loss which one to select: vererbbarer Nießbrauchliterally heritable right to use, vererbbare Fruchtnießung-literally heritable right to enjoy benefits, vererbbares Nutzungsrecht-literally heritable right to use, Nießbrauchsrecht-literally right to use.

\section{Stużebność przesytu}

A real property may be burdened in favour of a utility company. If the company owns structures for transporting fluids, steam, gas, electricity or similar ones located on another person's real property, or if the company intends to build such structures on it, this company is entitled to use the real property to such an extent that is necessary to build the structures or ensure their proper functioning. For instance, the company's employees have the right to enter the burdened real property in order to repair the structures, maintain, or modernize them. The real property's owner cannot successfully object the imposition of such a burden on the property, but they are authorized to receive consideration for the use of their property.

The legal solution in question became part of Polish law in 2008, and therefore the term stużebność przesytu cannot be found in Wojtasiewicz [35] and Kozierkiewicz. It is also absent in Ożga and the PWN-Oxford dictionary [37]. Kucharska [34, p. 133] translates it as transmission easement, and in the PWN.PL translation it is rendered in a similar manner as easement of transmission. This is an acceptable option, a literal translation that is likely to be understood. A solution ensuring 
idiomaticity would be to use a similar institution called utility easement. Denise L. Evans and O. William Evans [12, p. 426] define a utility easement as "a right to use another's property for purposes of laying water and sewer lines, gas lines, or bringing in electric or telecommunications services."

The names of easements existing under Polish civil law do not generally pose problems in translation into German. This is due to historical reasons because German law in particular, apart from French law, was the most influential legal system in continental Europe, also materially affecting Polish civil law. Therefore, Polish easements can be easily matched with German equivalents. Where there are two German versions of an easement name, the one with the term Recht is more formal, and the one with the term Dienstbarkeit less formal; however, both convey the exact sense of the Polish term.

\begin{tabular}{lll}
\hline stużebność gruntowa & - & Grunddienstbarkeit \\
\hline stużebność przesyłu & Leitungsrecht & Leitungsdienstbarkeit \\
stużebność drogi koniecznej & Notwegrecht & Notwegdienstbarkeit \\
stużebność przechodu i przejazdu & $\begin{array}{l}\text { Geh- und Durchfahrtrecht } \\
\text { (Wegerecht) }\end{array}$ & Wegdienstbarkeit \\
stużebność mieszkania & Wohnrecht or Wohnungsrecht & \\
stużebność budynkowa & & Gebäudedienstbarkeit
\end{tabular}

It is worth emphasizing that Austrian lawyers to render the term stużebność (easement) use more frequently a word derived from Latin, Servitut, rather than Dienstbarkeit. Servitut can be, for instance, found in the Austrian Civil Code $(A B G B)$. The same Latin-derived word serwitut is also a part of Polish vocabulary but is considered colloquial and outdated. In the case of some types of easements in Austria, less formal terms are sometimes used, as in Germany. For instance, instead of the official term Wegerecht, the compound Felddienstbarkeit may be employed (such a compound is not known in Germany). In Switzerland, a right of way on foot and a vehicular right of way are described together as Fussund Fahrwegrecht. In this case, the compound has been created on the basis of the name for a footpath (Fussweg) and the name for a carriageway (Fahrweg). Moreover, the Swiss name for a right of way-Wegrecht-is structurally different from the term used in Germany and Austria-Wegerecht-because it does not include the linking element $e$.

\section{Rękojmia wiary publicznej ksiag wieczystych}

The term means that-under certain conditions-one can rely on the content of title registers, and if the conditions are met (for instance lack of bad faith), a transaction based on the content of a title register is valid in law.

A similar institution exists in, for example, the English legal system:

For land registration to eliminate the need for the purchaser to investigate title, it must go one step further than gathering together in the register information 
about who has rights over the land. It must also guarantee the truth of what it says about ownership of land. As well as telling a prospective purchaser or lender 'there are no unregistered interests in this land' (which the register says with some qualification, particularly to protect those who have property rights and are actually in occupation of the land) it must also say 'the registered proprietor owns the land and can transfer it to you'. That is known as the guarantee of title or the 'title promise', which is reinforced by provision for payment of compensation (or an 'indemnity') if the register turns out to be wrong. (...) By providing an accurate statement of property rights in relation to land, and by guaranteeing the correctness of that statement, the register of title makes conveyancing faster, easier and cheaper ${ }^{41}$ [18, p. 3].

The phrase does not appear in the Polish Civil Code, nor can it be found in Kozierkiewicz or the PWN-Oxford dictionary. It was rendered as warranty of authenticity of a land and mortgage register in the PWN.PL translation and its shortened version as principles of public credibility (rękojmia wiary publicznej) in Ożga [22, p. 414]. The term warranty of authenticity strongly correlates with works of art and in the context strikes the reader as decidedly odd. The other rendering, principles of public credibility, brings to mind not title registers, but the PR sector and the rules for being credible to the public. Both phrases trigger wrong associations, and it is advisable to avoid them, especially that a naturally sounding and easily understandable phrase might be coined: the guarantee of title provided by title registers.

Rendering the term in German does not present any difficulties. A functional equivalent of the phrase can be found in article 892 of the BGB-öffentlicher Glaube des Grundbuchs. A translator may apply this equivalent or its extended version faithfully following the original expression-Gewähr des öffentlichen Glaubens der Grundbücher, which solution has been adopted by, for instance, Dariusz Łubowski [23, p. 265] and Marcin Zaremba [38, p. 131].

\section{H Referendarz sqdowy}

Michał Szwast states that the office of referendarz sadowy appeared in the Polish legal system in 1998. The office was created in order to deal with a growing number of court cases and in order to follow international recommendations. Since then, the role of referendarz sqdowy within the judiciary system has assumed increasing importance. From a modest judicial official responsible for keeping title registers and court registers, referendarz sqdowy has metamorphosed into a judicial official wielding a very wide range of powers previously reserved only for judges [32, p. 1]. Under article 2(2) of the Act of 27 July 2011 on the Organization of Courts of General Jurisdiction, referendarz sqdowy performs in courts legal protection tasks other than the administration of justice. This means that they are not allowed to adjudicate legal disputes or adjudicate whether criminal charges are grounded (cf. $[11$, p. 595]), but they can perform other courts' duties, such as ruling on the binding character of a judicial decision or taking certain actions relating to the provision of

41 Emphasis added. 
domestic and international legal assistance. Among the conditions that must be met to be eligible for the post of referendarz sqdowy, there is a requirement of holding a master's degree in law and a requirement of passing one of post-degree legal exams (for instance the exam to become a judge) or completing a specific post-degree legal traineeship (for instance a judge traineeship). Thus, referendarz sqdowy is a highly qualified lawyer performing certain judicial duties. However, as stated in an opinion prepared by the Association of Polish Judges "Iustitia" [Stowarzyszenie Sędziów Polskich Iustitia], referendarz sqdowy's duties are distinctly unlike a judge's duties: although the office holders make judicial decisions, those decisions are either of a formal character or of a registration nature. ${ }^{42}$

The office of referendarz sadowy in the Polish legal system is based on the AustroGerman model: a similar office in Austria and Germany is called Rechtspfleger [27, pp. 140-143]. The European Union of Rechtspfleger gathers national associations for Rechtspflegers and holders of the office similar to the office of Rechtspfleger. According to its website, it currently has full member organizations from 14 states: Austria, Bulgaria, the Czech Republic, Denmark, Estonia, France, Germany, Italy, Luxembourg, Poland, Portugal, Romania, Spain, and the Netherlands. ${ }^{43}$ As can be seen, there are no associations from English-speaking countries, and on the website the office name is given either in German (Rechtspfleger) or French (greffier). As the office is modelled on the Austro-German institution, its translation into German does not pose any problems, unlike its translation into English for it is difficult to find a comparable post in English language jurisdictions. ${ }^{44}$ The Polish Civil Code does not contain the term, and it is not included in either Kozierkiewicz, Ożga, or the PWN-Oxford dictionary. In the PWN.PL translation, the phrase is rendered as court clerk. However, this translation is highly misleading. In the context of English law,

court clerks are also known as court legal advisers and are qualified barristers or solicitors that are assigned to work with magistrates. Court clerks work alongside magistrates that are presiding over criminal cases or specific civil proceedings, providing them with advice on applicable laws and judicial procedures. The magistrate considers and analyses the facts of the case and the clerk provides them with guidance on the legal concepts, precedents and rules, which are relevant to the matter being heard. They also make sure that court proceedings move along smoothly, explain procedures to defendants and witnesses in order to avoid disruptions and make sure that all the people involved in court proceedings conform to the conventions of the court. ${ }^{45}$

\footnotetext{
${ }^{42}$ The Association of Polish Judges "Iustitia". An opinion. https://www.iustitia.pl/dzialalnosc/opinie-iraporty/925-opinia-iustitii-dotyczaca-przywrocenia-asesury (accessed on 8 July 2020).

${ }^{43}$ The European Union of Rechtspfleger. Full members. https://eur-online.eu/en/ordentliche-mitglieder / (accessed on 9 July 2020).

${ }^{44}$ The term Rechtspfleger is sometimes translated into English as registrar or master (PONS online dictionary; https://en.pons.com/translate/german-english/Rechtspfleger; accessed on 5 September 2020), but the level of resemblance between the posts is dangerously low. Moreover, the term registrar has varying meanings in various English language jurisdictions, and both English terms are polysemous, which might lead to confusion.

45 allabout ${ }^{\mathrm{TM}}$ law.co.uk. Court careers. https://www.allaboutlaw.co.uk/law-careers/what-can-i-do-with-alaw-degree/court-careers (accessed on 9 July 2020).
} 
The above definition clearly shows the danger of making use of terms from a different legal system without due consideration: even a superficial comparison of both offices reveals major discrepancies between referendarz sadowy and court clerk. In order not to abuse the original term, possibly the only viable solution is to provide a short definition that would incorporate the most characteristic features of the office. The presence of a definition will open a range of options for dealing with the term itself, such as leaving it untranslated or translating it in a selected manner. The translation could draw on the Latin heritage of Polish and English: referendarz comes from medieval Latin referendarius, ${ }^{46}$ English has the word referendary, with roots in late Latin referendarius. ${ }^{47}$ The identity of the origin of both words might justify the translation of referendarz sqdowy as court referendary.

\section{F Lokal}

From a legal perspective, lokal is a building's separated part for residential or other purposes; if this part is self-contained, it may constitute a separate real property [13, pp. 96-97]. Consequently, the term may refer to a flat, an office, a shop, or a garage.

Because the term has a specific legal meaning, scrupulous care must be taken while translating it, especially in the context of real property documents. In the PWN.PL translation, lokal is rendered as premises. The same equivalent is used by Ożga [22, p. 187], Kucharska [34, p. 301], and Kozierkiewicz (lokale i budynkipremises and buildings, [16, p. 198]). The PWN-Oxford dictionary goes for flat and apartment. Wojtasiewicz [35, p. 125] chooses two phrases to render the term: living accommodation and business premises.

Neither translation is satisfactory or fully satisfactory. The word premises abuses the original term in the most conspicuous manner. Collins online English dictionary defines premises as "a piece of land together with its buildings, esp. considered as a place of business". ${ }^{48}$ Macmillan dictionary even more forcefully connects the word with a non-residential use: "the buildings and land that a business or organization uses". ${ }^{49}$ Dictionary of law [7, p. 231] describes premises as "building and the land it stands on", and A dictionary of law [20, p. 376] as "land or buildings; a parcel of land". According to The complete real estate encyclopedia [12, p. 312], the term premises refers to

land and improvements, generally, but the definition depends on context, case authority, and statutory description. Premises may be narrowed to one room if

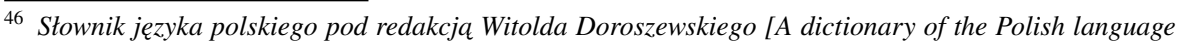
edited by Witold Doroszewski]. http://doroszewski.pwn.pl/haslo/referendarz/ (accessed on 10 July 2020).

${ }^{47}$ Merriam-Webster dictionary. https://www.merriam-webster.com/dictionary/referendary (accessed on 10 July 2020).

${ }^{48}$ Collins online English dictionary. https://www.collinsdictionary.com/dictionary/english/premises (accessed on 10 July 2020).

${ }^{49}$ Macmillan dictionary. https://www.macmillandictionary.com/dictionary/american/premises (accessed on 10 July 2020).
} 


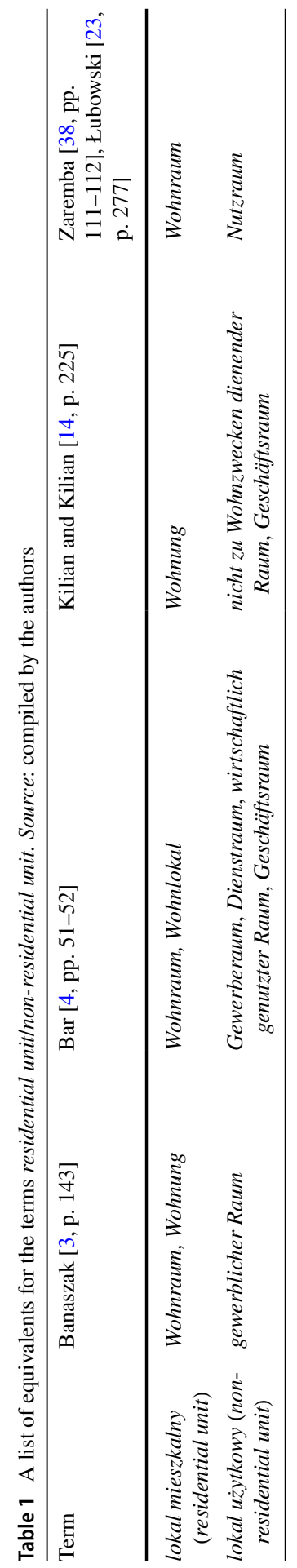


a search warrant gives the right to search certain described premises. It could

be the entire house and surrounding 160 acres under other circumstances.

As can be seen, the word premises typically denotes land with a building or buildings on it used for business purposes or by an organization. It may also refer to land only, a building or buildings only, or even one room only. Lokal does not fit this denotation for three reasons. Firstly, it does not match the typical meaning of premises at all (lokal is a separated part of a building), secondly, the meaning of lokal is not that broad (it cannot mean for instance "the entire house and surrounding 160 acres"), and thirdly, unlike premises, lokal strongly correlates with both a residential use and a non-residential use.

Kozierkiewicz's translation is unclear as the word premises also covers buildings, so it is difficult to grasp how they are different (this might be compared to saying "furniture and chairs"). The equivalent in the PWN-Oxford dictionary is too narrow: lokal does not only refer to flats/apartments. The Wojtasiewicz's option is both too broad and too narrow: living accommodation can be any type of residential dwelling, and business premises do not cover for example garages.

A viable solution can be achieved by looking at the institution of commonhold and its concept of a unit: "A unit may be a flat, or it may be used for a business (such as an office or shop), and could include a garage or a parking space". ${ }^{50}$ The equivalent (non-)residential unit is likely to give a better idea of what lokal is than any other out of the options listed above.

In German, there are two close equivalents for the term in question: Raum or Räumlichkeit. The term's two subtypes are often translated in the following manner (Table 1).

As to the translations of the term lokal mieszkalny, all proposals are acceptable apart from Wohnlokal: this compound is not used in German in legal contexts. As to the translations of the term lokal użtkowy, the best option is Nutzraum as it is terse and adequately general. From a semantic perspective, a good solution is offered by Alina Kilian and Agnieszka Kilian—nicht zu Wohnzwecken dienender Raum. However, it is tainted by its wordiness resulting from the structural limitations of the German language. The remaining versions restrict the meaning of the original expression to a greater or lesser degree because a non-residential unit may be used not only as a business space (gewerblich, Gewerbe, wirtschaftlich, Geschäft) or an office space (Dienst), which they suggest. Those versions are fully appropriate only in specific contexts but as a general term are more or less abusive depending on the level of their generality (the more general-the less abusive).

\section{G Spótdzielcze własnościowe prawo do lokalu}

This is a limited property right related to (non-)residential units. It is close to ownership in practical terms but formally not equivalent to ownership. It is similar to ownership because we can use a (non-)residential unit to which we have

\footnotetext{
${ }^{50}$ Lease. The Leasehold Advisory Service. Commonhold. https://www.lease-advice.org/advice-guide/ commonhold/ (accessed on 10 July 2020).
} 
the right generally in a way an owner can, and we can dispose of this right, for instance sell it. What is more, a title register may be created for this right. However, we are not owners of the unit: its owner is a housing cooperative. If a title register is created for such a unit, we are not called owners in it but entitled persons. There are also certain limitations in the use of our unit: for instance, if we want to convert our residential unit into a non-residential unit, we have to be given consent by the housing cooperative, which would not be necessary if we owned the unit. As has already been said, the right in question is still in existence, but it cannot be granted any more as this possibility was repealed in 2007.

This specific legal institution is similar to leasehold (we are users rather than owners), commonhold, and the tenement system (the idea of communal living), but unlike leasehold, there is no time limit, and-unlike commonhold and the tenement system-there is no ownership. These important discrepancies forbid the translator to use the concepts in order not to abuse the original idea. Consequently, the translator has to resort to coinage or partial coinage.

The term is not included in Ożga, Kozierkiewicz, or the PWN-Oxford dictionary. Wojtasiewicz translated its previous version, which differs from the current one. Kucharska [34, p. 113] uses the phrase cooperative ownership right to premises, and in the PWN.PL translation the term is rendered as cooperative title to premises. The issue of translating the word lokal as premises has already been considered. As for the remaining part, the abusive character of the words ownership and title (the legal solution in question does not vest ownership, it is only ownership-like) is mitigated by the qualified influence of the adjective cooperative and the fact that we deal with something closely resembling ownership. Though acceptable, both translations do little to offer the recipient any real insight into the meaning of the concept. Such an insight could be gained if we translated the phrase as unlimited leasehold of a (non-)residential unit.

Marcin Zaremba [38, p. 134] has translated the term into German in the following manner: genossenschaftliches Eigentumsrecht an einem Raum (Wohnoder Gewerberaum) [cooperative ownership right to a (non-)residential unit (a flat or a business space)], providing in brackets two types of units the right refers to. The translation is acceptable but not ideal due to the reservations expressed above with regard to the English version following the same strategy (ownership, lack of insight) and with regard to Gewerberaum. Moreover, the translator is inconsistent because previously the term now rendered as Gewerberaum has been translated as Nutzraum. Another option is offered by Alina Kilian and Agnieszka Kilian [14, p. 435]: genossenschaftliches Eigentumsrecht an einer Wohnung/an nicht zu Wohnzwecken dienendem Raum [cooperative ownership right to a flat/a non-residential unit]. In this case, there is no problem with the too limited meaning of Gewerberaum but at the cost of circumlocution, and the remaining reservations still apply.

In German-speaking countries, there is no exact equivalent of the Polish right in question, something quite similar, however, might be found in Germany. It is possible to live there in a flat without being its owner but having the right to live in the flat permanently. Such a right is called Dauerwohnrecht, and it is inheritable and transferable. German law also includes an inheritable and transferable right to use a 
non-residential unit on a permanent basis-Dauernutzungsrecht. Both rights may be entered in a title register. As a result, the phrase Dauerwohn- oder Dauernutzungsrecht can be successfully applied as a functional equivalent of the Polish term.

\section{$\mathrm{H}$ z urzędu}

The phrase $z$ urzedu is usually translated into English as ex officio (cf. [22, p. 575]). This strategy was also adopted in the PWN.PL translation, in which all instances of the phrase in question were rendered in the manner described. However, on closer examination of the meaning of the Latin phrase ex officio in English and the meaning of the Polish phrase $z$ urzedu, it turns out that the application of the Latin phrase as it functions in English abuses the original meaning.

As Izabella Czerkawska, a district court judge, explains, the phrase $z$ urzędu means that an authority takes action without any request in contrast to taking action upon request. ${ }^{51}$ Likewise, the online Great dictionary of the Polish language defines the phrase in the following manner: "under applicable law, without the need to make a request by anybody". 52 The phrase is employed when somebody wants to point out that a certain step may or must be taken by an authority itself without requiring a request from a person or another authority. Thus, some offences are prosecuted by the police or the prosecution service upon learning by them that they might have been committed without any outside request to do so (for instance murder), and some offences are prosecuted only upon the victim's request (for instance direct exposure of another person to HIV infection). Similarly, in some cases a statement of grounds for a judgment is prepared without any request, and in some cases only upon a party's request.

The meaning of the Latin phrase ex officio as used in English does not correspond with the above explanations. Four dictionaries (including three legal ones) give the following definitions of the phrase at issue: "a Latin phrase meaning 'because of an office held'. The treasurer is ex officio a member or an ex officio member of the finance committee" [7, p. 115]; "by virtue of holding an office. Thus, the Lord Chief Justice is ex officio a member of the Court of Appeal" [20, p. 192]; "Latin for "from the office.' Used when someone holds one position because of the authority he or she has from another position (such as being on a committee simply because one is president of the corporation)"; "h3 "holding a position or membership due to the power or influence of one's office, and not by election or appointment. A chairperson, for example, can be an ex-officio member of all board appointed committees. Such positions and their attached voting and other privileges are detailed in the bylaws of the organization. Latin for, because of one's office". ${ }^{54}$ Clearly, all these

\footnotetext{
${ }^{51}$ Izabella Czerkawska. 2017. An educational leaflet. http://www.plock.so.gov. pl>edukacja $2017>26092017$ (accessed on 17 July 2020).

52 Wielki stownik języka polskiego. https://wsjp.pl/index.php?id_hasla=24373\&ind=0\&w_szuka $\mathrm{j}=\mathrm{urz} \% \mathrm{C} 4 \% 85 \mathrm{~d}$ (accessed on 17 July 2020; translated by J.G. and A.D.K.).

${ }^{53}$ Nolo's free dictionary of law terms and legal definitions. https://www.nolo.com/dictionary/ex-officioterm.html (accessed on 17 July 2020).

${ }^{54}$ BusinessDictionary. http://www.businessdictionary.com/definition/ex-officio.html (accessed on 17 July 2020).
} 
definitions or examples refer to a corollary membership or position. A broader definition comes from West's encyclopedia of American law [19, p. 258]: "By virtue of the characteristics inherent in the holding of a particular office without the need of specific authorization or appointment. The phrase ex officio refers to powers that, while not expressly conferred upon an official, are necessarily implied in the office. A judge has ex officio powers of a conservator of the peace."

The definitions presented lead to the conclusion that the phrase ex officio does not convey the most important characteristic of the original phrase z urzedu, namely, that a step is taken on an authority's initiative, be it obligatory or otherwise, without any request being made. Here the abuse of the source term stems from a misplaced reliance on the Latin language (the Latin abuse as contrasted with the Latin heritage).

In German, on the other hand, the term does not pose any problems as it has a precise equivalent, von Amts wegen.

\section{Conclusion}

As we have observed, a third space plays a pivotal role in pinning down the most suitable equivalents. Relying on insights gained through it allows translators to avoid transgressions and ensure the aptness of renderings. A third space is a place where legal concepts coming from various jurisdictions intersect, revealing either their solitary nature within the systems being compared or the extent to which they overlap. It is where high and low connectivity [36, p. 173] is discovered, where traumatic treatment of terms is discerned, and where expressions that preserved (inherited) their "original significances" [36, p. 185] are clearly seen.

Any third space is characterized by its intense hybridization, which results from an influx of concepts and ideas from various cultures. In stark contrast to the sources of incoming elements, no homogeneity, unity, or consistency can be found there. However, the emergent alien landscape provides translators with a unique opportunity of making informed observations as to the nature of relationships between the terms filling up a third space. As they can be found in one place, it is thus possible to juxtapose them with each other in order to see to what extent they are related, whether their function is identical, similar or markedly dissimilar, and what kind of connectivity exists between them.

Our third space has been filled up with Polish land registration concepts and related concepts from various English and German language jurisdictions. We have then followed the algorithmic procedure proposed by Anne Wagner: examining concepts, processing their variables, searching for the intercorrelations between the variables in order to come up with the most suitable translation.

Our analysis based on the investigation of the third space content has allowed us to find: 
(a) High connectivity concepts, which preserve (inherit) the original meanings and substantiate the substitution of terms: there is a high degree of identity between such terms as ksiega wieczysta, title register, title sheet, folio, and Grundbuch; between referendarz sqdowy and Rechtspfleger; between stużebność przesytu and Leitungsrecht; between rękojmia wiary publicznej ksiag wieczystych and öffentlicher Glaube des Grundbuchs; as well as between użytkowanie wieczyste, long-term lease, and Erbbaurecht;

(b) Concepts showing no or hardly any connectivity, which leads to the abuse of the original meanings: under no circumstances can a court clerk be equated with referendarz sqdowy; marked differences can be observed between ksiega wieczysta and register of deeds; also warranty of authenticity and principles of public credibility for rękojmia wiary publicznej strike the wrong note;

(c) Concepts with varying degrees of connectivity, which partly preserve (inherit) the original meanings and substantiate the substitution of terms only in specific contexts: lokal in some cases in fact refers to a flat/apartment, and in some situations lokal użytkowy actually denotes Geschäftsraum, but the terms' general meaning is broader;

(d) Hybridized discourse instances, where a translator opts for a mixture of native and alien measures: służebność przesyłu rendered as transmission easement or easement of transmission at the same time relies on the source (transmission) and target (easement) cultures, leading to the creation of an understandable though unidiomatic phrase; bidirectional references can be found in the renderings of spółdzielcze własnościowe prawo do lokalu as unlimited leasehold of a (non-) residential unit and as genossenschaftliches Eigentumsrecht an einer Wohnung/ an nicht zu Wohnzwecken dienendem Raum or użytkowanie wieczyste as Erbnießbrauch because although the phrases utilize target culture concepts as building blocks, the entire terminological structure sounds unfamiliar and foreign.

Additionally, we have discovered that the Latin heritage may prove beneficial or abusive. The English term referendary and the Polish term referendarz derive from the same Latin word referendarius, by the same token opening up an opportunity of rendering the latter as the former with some necessary explanations added. On the other hand, the Latin phrase ex officio as used in English abuses the meaning of the Polish phrase z urzedu for it does not include the crucial characteristics of the Polish term. Therefore the Latin heritage can be resorted to only after its careful consideration in a third space.

Open Access This article is licensed under a Creative Commons Attribution 4.0 International License, which permits use, sharing, adaptation, distribution and reproduction in any medium or format, as long as you give appropriate credit to the original author(s) and the source, provide a link to the Creative Commons licence, and indicate if changes were made. The images or other third party material in this article are included in the article's Creative Commons licence, unless indicated otherwise in a credit line to the material. If material is not included in the article's Creative Commons licence and your intended use is not permitted by statutory regulation or exceeds the permitted use, you will need to obtain permission directly from the copyright holder. To view a copy of this licence, visit http://creativecommons.org/licen ses/by/4.0/. 


\section{References}

1. Ashcroft, J.D., K.M. Ashcroft, and M.A. Patterson. 2014. Law for business. 18th edition. SouthWestern Cengage Learning.

2. Baker, C. 2005. Commonhold. PracticalConveyancing.co.uk.

3. Banaszak, B. (ed.). 2003. Stownik prawa i gospodarki polsko-niemiecki. Warszawa: Wydawnictwo C.H.Beck.

4. Bar, L. (ed.). 1987. Stownik prawniczy polsko-niemiecki. Wrocław: Ossolineum.

5. Blajer, P. 2015. Z historii ksiagg gruntowych (Grundbücher). Studia Prawnicze. Rozprawy $i$ Materiaty. Studies in Law: Research Papers 2 (17): 65-109.

6. Cao, D. 2007. Translating law. Clevedon: Multilingual Matters Ltd.

7. Collin, P.H. (ed.). 2004. Dictionary of law, 4th ed. London: Bloomsbury Publishing Plc.

8. Cooke, E. 2003. The new law of land registration. Oxford and Portland, Oregon: Hart Publishing.

9. Creifelds, C. 2000. Rechtswörterbuch, 16th ed. München: Verlag C.H.Beck.

10. Dickson, B. 2018. Law in Northern Ireland, 3rd ed. Oxford: Hart Publishing. Bloomsbury Publishing Plc.

11. Ereciński, T., J. Gudowski, and J. Iwulski. 2009. Prawo o ustroju sqdów powszechnych. Ustawa o Krajowej Radzie Sadownictwa. Komentarz, 2nd edition. Warszawa: LexisNexis. In Wyrok Trybunatu Konstytucyjnego z dnia 13 marca 2012 r. P 39/10.

12. Evans, D.L., and O.W. Evans. 2007. The complete real estate encyclopedia. New York: McGraw-Hill.

13. Kaczor, A., A. Klimczyk, P. Pucher, R.T. Skowron, R. Wypiór, and G. Zawada. 2008. Leksykon nieruchomości. Warszawa: Oficyna, a Wolters Kluwer business.

14. Kilian, A., and A. Kilian. 2014. Stownik jezzyka prawniczego i ekonomicznego polsko-niemiecki. Warszawa: Lex, a Wolters Kluwer business.

15. Kleniewska, I. 2003. Zakres stosowania wpisu konstytutywnego w europejskich systemach rejestracji nieruchomości. Warszawa: Instytut Wymiaru Sprawiedliwości.

16. Kozierkiewicz, R. 2005. Dictionary of business terms. Vol. 2 Polish-English. Warszawa: Wydawnictwo C.H.Beck.

17. Law Commission. 2016. Updating the land registration act 2002. A consultation paper. Consultation Paper No 227.

18. Law Commission. 2018. Updating the land registration act 2002. Summary. Law Com No 380.

19. Lehman, J., and S. Phelps eds. 2005. West's encyclopedia of American law, 2nd edition. vol. 4. Detroit: Thomson Gale.

20. Martin, E.A. (ed.). 2003. A dictionary of law, 5th ed. Oxford: Oxford University Press.

21. Matulewska, A. 2014. In quest of sufficient equivalence. Polish and English insolvency terminology in translation. A comparative study. Studies in Logic, Grammar and Rhetoric 38 (51): 167-188.

22. Ożga, E. 2009. The great dictionary of law and economics. Vol. 2 Polish-English. Warszawa: Wydawnictwo C.H.Beck.

23. Polnisches Bankenrecht. Gesetz über Grundbücher und Hypothek. Zweisprachige Textausgabe Polnisch-Deutsch, trans. D. Łubowski. 2005. Warszawa: Wydawnictwo C.H.Beck.

24. Pommer, S. 2012. The hermeneutic approach in legal translation. In Unterwegs zu einer hermeneutischen Übersetzungswissenschaft: Radegundis Stolze zu ihrem 60. Geburtstag, ed. L. Cercel and J. Stanley. Tübingen: Gunter Narr Verlag.

25. Revenue. Irish Tax and Customs. 2019. Tax and duty manual. Property searches using PRAI and ST21 returns and property valuations.

26. Rutherford, J. 1990. The third space. Interview with Homi Bhabha. In Identity: community, culture, difference, ed. J. Rutherford. London: Lawrence and Wishart Limited.

27. Rylski, P. 2011. Pozycja ustrojowa i procesowa referendarza sądowego w postępowaniu cywilnym. Prawo w Działaniu. Sprawy Cywilne 10: 139-186.

28. Snell-Hornby, M. 2006. The turns of translation studies. Amsterdam/Philadephia: John Benjamins Publishing Company.

29. Society of Chartered Surveyors Ireland. Boundaries: procedures for boundary identification, demarcation and dispute resolution in Ireland, 2nd edition.

30. Stanfield, J.D., J. Underwood, K. Gunaskera, and C. Ernst. 2008. Land registration and land fraud in the United States. A paper presented to the Seminar on Risk Reduction in Land Fraud. Grand Blue Wave Hotel. Malaysia. 
31. Strzelczyk, R. 2017. Prawo nieruchomości, 5th ed. Warszawa: Wydawnictwo C.H.Beck.

32. Szwast, M. 2016. Referendarz sqdowy w sqdownictwie powszechnym—status prawny, rozwój kompetencji i jego ograniczenia. Analizy i Rekomendacje 2. Helsińska Fundacja Praw Człowieka.

33. The Act of 6 July 1982 on Title Registers and Mortgages, trans. Centrum Tłumaczeń PWN.PL [PWN.PL Translation Centre].

34. The Civil Code. Kodeks cywilny, trans. E. Kucharska. 2011. Warszawa: Wydawnictwo C.H.Beck.

35. The Polish Civil Code, trans. O. Wojtasiewicz. 2000. Warszawa: Tepis Publishing House.

36. Wagner, A. 2016. A space in-between-legal translation as a 'third space'. Journal of Civil Law Studies 9: 168-190.

37. Wielki multimedialny stownik angielsko-polski polsko-angielski PWN-Oxford. 2016. Warszawa: Wydawnictwo Naukowe PWN SA.

38. Zaremba, M. 2007. Immobilienwirtschaft in Polen und Deutschland. Praxishandbuch. Warszawa: Wydawnictwo C.H.Beck.

Publisher's Note Springer Nature remains neutral with regard to jurisdictional claims in published maps and institutional affiliations. 